\title{
The effect of zinc supplementation on body composition and hormone levels related to adiposity among children: a systematic review
}

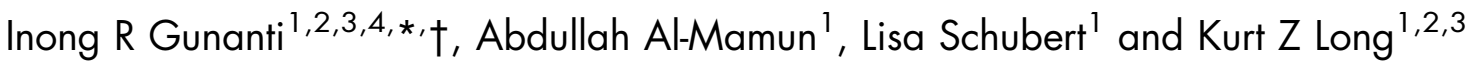 \\ ${ }^{1}$ School of Public Health, Faculty of Medicine and Biomedical Sciences, The University of Queensland, Brisbane, \\ Queensland, Australia: ${ }^{2}$ Department of Epidemiology and Public Health, Swiss Tropical Institute of Public Health, \\ Basel, Switzerland: ${ }^{3}$ School of Medicine, Faculty of Medicine and Biomedical Sciences, The University of \\ Queensland, Child Health Research Centre, Brisbane, Queensland, Australia: ${ }^{4}$ Faculty of Public Health, Universitas \\ Airlangga, Public Health Nutrition Department, Surabaya, East Java, Indonesia
}

Submitted 23 June 2015: Final revision received 31 January 2016: Accepted 12 April 2016: First published online 20 May 2016

\begin{abstract}
Objective: To provide a comprehensive synthesis of the effects of Zn supplementation on childhood body composition and adiposity-related hormone levels. Design: Five electronic databases were searched for randomized controlled trials of $\mathrm{Zn}$ supplementation studies published before 28 February 2015. No statistical pooling of results was carried out due to diversity in study designs.

Setting: Community- or hospital-based, from fourteen developing and developed countries.

Subjects: Children and adolescents aged 0 to 10 years.

Results: Seven of the fourteen studies reported an overall or subgroup effect of $\mathrm{Zn}$ supplementation on at least one parameter of body composition, when determined by anthropometric measurements (increased mid upper-arm circumference, triceps skinfold, subscapular skinfold and mid upper-arm muscle area, and decreased BMI). Three out of the fourteen studies reported increased mean value of total body water estimated by bio-impedance analysis and increased fat-free mass estimated by dual energy X-ray absorptiometry and by total body water. Zn supplementation was associated with increased fat-free mass among stunted children. One study found supplementation decreased leptin and insulin concentrations.

Conclusions: Due to the use of anthropometry when determining body composition, a majority of the studies could not accurately address whether alterations in the fat and/or fat-free mass components of the body were responsible for the observed changes in body composition. The effect of $\mathrm{Zn}$ supplementation on body composition is not consistent but may modify fat-free mass among children with pre-existing growth failure.
\end{abstract}

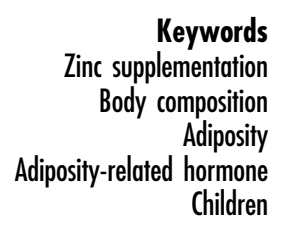

The rapid increase in the prevalence of overweight and obesity in many parts of the world is now characterized as a global pandemic and so has become one of the more important contemporary public health issues ${ }^{(1,2)}$. Recent evidence suggests that the status of micronutrients such as vitamin $\mathrm{A}^{(3)}$, vitamin $\mathrm{D}^{(4)}$, vitamin $\mathrm{B}^{(5)}$ and $\mathrm{Zn}^{(6)}$ may affect energy balance and so play a role in obesity. Obese individuals have lower blood micronutrient concentrations

†Correspondence address: Child Health Research Centre, 62 Graham Street, South Brisbane, QLD 4101, Australia. while micronutrient deficiencies are associated with increased fat deposition in both animal models and epidemiological studies ${ }^{(7)}$. Micronutrient supplementation of obese adults can lead to reductions in body weight, BMI and abdominal obesity, and improve serum lipid profiles, possibly through increased energy expenditure and fat oxidation ${ }^{(8)}$.

Obese adults have been found to have significantly lower serum $\mathrm{Zn}$ concentrations while $\mathrm{Zn}$ deficiency has been found to be a risk factor for central adiposity among Indian men ${ }^{(9,10)}$. Similarly, children with low hair $\mathrm{Zn}$ 
concentrations in Guatemala, New Zealand, Malawi and Ghana have been found to have higher weight-for-age $Z$-scores, higher BMI and lower mid upper-arm muscle area (MAMA) compared with children with greater hair Zn concentrations ${ }^{(11-13)}$. Other studies, in contrast, have found no differences in serum Zn concentrations between obese and normal-weight individuals ${ }^{(14,15)}$. However, $\mathrm{Zn}$ supplementation has been found to be associated with greater weight gain and increased lean tissue mass simultaneously with increased linear growth among malnourished and stunted children ${ }^{(16-18)}$.

Zn may determine body adiposity through its role in energy metabolism, appetite control and adipokine regulation. Marginal $\mathrm{Zn}$ deficiency solely or in conjunction with a low-protein diet is associated with reduced lean body mass, decreased appetite and excess adiposity, each of which can be altered or restored by $\mathrm{Zn}$ supplementation $^{(19,20)}$. $\mathrm{Zn}$ is an important component of enzymes involved in energy metabolism and $\mathrm{Zn}$ metalloenzymes essential for nucleic acid and protein synthesis and new tissue synthesis ${ }^{(21)}$. It also regulates the hormones leptin, ghrelin, insulin and adiponectin, which, in turn, regulate adiposity and fat mass ${ }^{(22-24)}$. Any changes in tissuespecific adipokine concentrations associated with $\mathrm{Zn}$ status may subsequently determine changes in adipose tissue mass and in turn modify the risk of obesity.

Clinical and epidemiological evidence suggests that $\mathrm{Zn}$ status may be contributing to the increased burden of obesity reported in countries passing through the epidemiological and nutrition transitions due to its effect on body composition $^{(10,18)}$. Meta-analyses have provided strong evidence for the growth-limiting effect of $\mathrm{Zn}$ deficiency ${ }^{(25)}$. There is increasing evidence that $\mathrm{Zn}$ status may play a role in determining both growth patterns and body adiposity ${ }^{(18,26)}$. Malnutrition in early childhood is associated with a greater risk of obesity and numerous chronic diseases later in life, possibly due to metabolic 'programming' and other physiological adaptations in response to nutrition constraints ${ }^{(27,28)}$. Such metabolic adaptations accompanying childhood stunting affect body fatness, growth rate, energy balance and fat oxidation, which can lead to obesity in the context of later availability of abundant energy (food) ${ }^{(29,30)}$. Pre-existing $\mathrm{Zn}$ deficiency may be contributing to the development of obesity via its relationship with fat deposition associated with childhood stunting and subsequent short stature.

There has been no systematic review to date of the effects of $\mathrm{Zn}$ supplementation on body adiposity and composition. Therefore, we carried out a review of the literature to clarify what is understood about the effects of Zn supplementation on children's body composition and address what factors may modify these associations. We also reviewed studies which reported the effect of $\mathrm{Zn}$ supplementation on adipokines and other hormones involved in adipogenesis that may be the mechanisms underlying associations between Zn status, body composition and risk of obesity.

\section{Methods and procedures}

\section{Search strategy}

A five-stage comprehensive search of the literature was conducted in the databases Cochrane Library, PubMed, Ovid Medline, CINAHL and EMBASE, for studies published before 28 February 2015. The search strategy for conducting the systematic review used the PICOS (Population, Intervention, Comparison, Outcome and Setting) method, in which search terms are separately developed for each component ${ }^{(31)}$ to identify studies which assessed children as the study population $(\mathrm{P})$ and supplementation with $\mathrm{Zn}$ alone or in combination with other micronutrients as the intervention/comparison (I/C). $\mathrm{Zn}$ could have been given with other micronutrients and the comparison group received the micronutrients (so that $\mathrm{Zn}$ was the only difference between the groups). Body composition, adiposity, leptin, ghrelin, insulin, adiponectin and adipokines are the outcomes (O) and studies conducted either in a community- or hospital-based setting from developing and developed countries (S). During the first stage the above databases were searched using the following keywords: 'Zinc' or 'Zn' or 'Zinc supplementation' or 'Zn supplementation' or 'Zinc therapy', AND 'child' or 'children' AND 'body composition' or ('adiposity', 'fat', 'fat free mass', 'weight', 'BMI', 'fat mass') or ('adipocytokine', 'adipokine', 'insulin', 'adiponectin', 'ghrelin', 'leptin').

In the second stage the total hits from the databases were pooled and duplicates were removed. This was followed by screening of the retrieved articles by reading the article 'title' in the third stage and the article 'abstract' in the fourth stage. In the fifth stage individual manuscripts were screened and those not satisfying inclusion criteria were excluded. To obtain additional data, a manual search of the reference lists of articles selected in the fifth stage was performed. This search process was conducted independently by two reviewers (I.R.G. and K.Z.L.) and the final group of articles to be included in the review was determined after an iterative consensus process. The present review was prepared in accordance with the PRISMA (Preferred Reporting Items for Systematic Reviews and Meta-Analyses) guidelines ${ }^{(32)}$.

The assessment of risk of bias within each study and the quality appraisal of each trial were evaluated using the quality checklists protocol of the CONSORT (Consolidated Standards of Reporting Trials) Statement 2001 for randomized controlled trials ${ }^{(33)}$. We appraised the methods section of the articles as the key quality parameters considered in the review (data not shown). However, since no quality evaluation of the studies was made, we did not exclude any studies due to concern about their quality.

We used the following inclusion and exclusion criteria: studies were included if they were controlled trials in human subjects, randomized trials of the effect of $\mathrm{Zn}$ supplementation efficacy (either as a single micronutrient 
or in combination with other micronutrients) on body composition and adiposity-related hormone levels among children aged from infant to adolescent, from both developing and developed countries, in peer-reviewed, English-language journals. Papers were excluded if they were single clinical case studies or clinical discussion papers, or not primary sources. Book chapters and review papers were not considered primary sources and were excluded. The reference lists and citations of articles identified from the electronic search were assessed to ensure the inclusion of additional relevant studies. No communications with individual researchers were made.

The outcomes of interest for the present review were the different measures of body composition defined as the characteristic size and distribution of the component parts of total body weight ${ }^{(34)}$. Body composition in studies included in the review was assessed using two methods: 'direct' and 'indirect' methods. Studies employing direct methods used such methods as dual-energy X-ray absorptiometry (DXA) with the use of a densitometer and total body water (TBW) by bio-impedance analysis (BIA) and ${ }^{2} \mathrm{H}$ dilution. These direct methods provide greater accuracy and rapid, non-invasive estimates of fat-free mass (FFM), fat mass (FM) and percentage body fat $(\% \mathrm{BF})^{(35)}$. The indirect method of assessing body composition in the reviewed studies was anthropometric measurements ${ }^{(35)}$. The anthropometric methods used in the reviewed studies included BMI determined by the relationship of body weight to body height, and skinfold thickness. Skinfold measurements can provide estimates of the size of the subcutaneous fat depot and body composition after applying equations to these measurements ${ }^{(36)}$. We included studies which reported on FFM outcomes using anthropometric measures of mid upper-arm circumference (MUAC), mid upper-arm fat area (MAFA) and MAMA, which are derived from MUAC and triceps skinfold $(\mathrm{TSF})^{(35)}$.

$\mathrm{Zn}$ plays a role in the regulation of adipokines and inflammatory responses, a mechanism which may underlie the effect of $\mathrm{Zn}$ supplementation on adiposity. Accordingly, studies that reviewed the effects of $\mathrm{Zn}$ on adipokines and other hormones involved in adipogenesis (leptin, ghrelin, adiponectin and insulin) were also screened as secondary outcomes for the present review.

\section{Evaluation of studies}

Information on study outcomes, body composition measures, and the location, study design, sample size and characteristics was extracted from each included study. The reviewed studies were heterogeneous in design and outcomes; therefore statistical pooling was not possible. Instead, findings are presented in narrative form in which bivariate and/or multivariate associations between $\mathrm{Zn}$ supplementation and adiposity and adiposity-related hormones are summarized in tables and text to aid data presentation where appropriate. As such, an effect of $\mathrm{Zn}$ supplementation was defined as a significant difference in body composition between $\mathrm{Zn}$ and control groups for at least one parameter of body composition or adiposityrelated hormone.

\section{Results}

\section{Search results}

The initial search identified 116 articles of which forty-two were identified as potentially eligible for inclusion after the screening of titles and abstracts. These articles were retrieved and reviewed in full, leading to the selection of sixteen articles reporting the effect of $\mathrm{Zn}$ supplementation on children's body composition in randomized controlled trials and five studies reporting $\mathrm{Zn}$ supplementation on adiposity-related hormones. Two of the studies on Zn supplementation on body composition ${ }^{(37,38)}$ were considered as randomized controlled trials although the children were randomized into different treatment arms/ multiple treatments instead of a placebo group. Two of the studies of $\mathrm{Zn}$ supplementation on body composition ${ }^{(17,39)}$ and one study of Zn supplementation on adiposity-related hormones ${ }^{(16)}$ were excluded due to their focus on childhood growth, morbidity and motor development, with no findings reported on the outcomes of interest. One study $^{(24)}$ was also excluded due to duplicate publication. This left fourteen studies on body composition and three studies $^{(40-42)}$ on adiposity-related hormone outcomes meeting the inclusion criteria and so were included in the present review (Fig. 1).

\section{Overview of findings}

Table 1 presents the summary characteristics of reviewed studies and Table 2 presents the method used for assessing body composition and main findings. Out of the fourteen studies of $\mathrm{Zn}$ supplementation on body composition, ten studies ${ }^{(37,38,42-49)}$ reported an overall or subgroup effect on at least one parameter of body composition, while the remaining four found no effects ${ }^{(50-53)}$.

Among the ten studies ${ }^{(37,38,42-49)}$ which reported an effect of $\mathrm{Zn}$ on body composition, three studies used direct measurements of body composition as well as the indirect measures ${ }^{(37,38,46)}$. Diaz-Gomez et al. ${ }^{(38)}$ reported higher mean values of TBW estimated by BIA among Zn-supplemented preterm infants in 6 months. No significant differences in subcutaneous fat accretion were found between children in the $\mathrm{Zn}$ and placebo groups, suggesting a positive effect of supplementation on FFM. Similarly, hospitalized children aged $4-10$ years with sickle cell anaemia who were supplemented with $\mathrm{Zn}$ over 12 months were found to have greater MUAC and MAMA $Z$-scores and improved rates of linear growth compared with children receiving the placebo, while no significant 


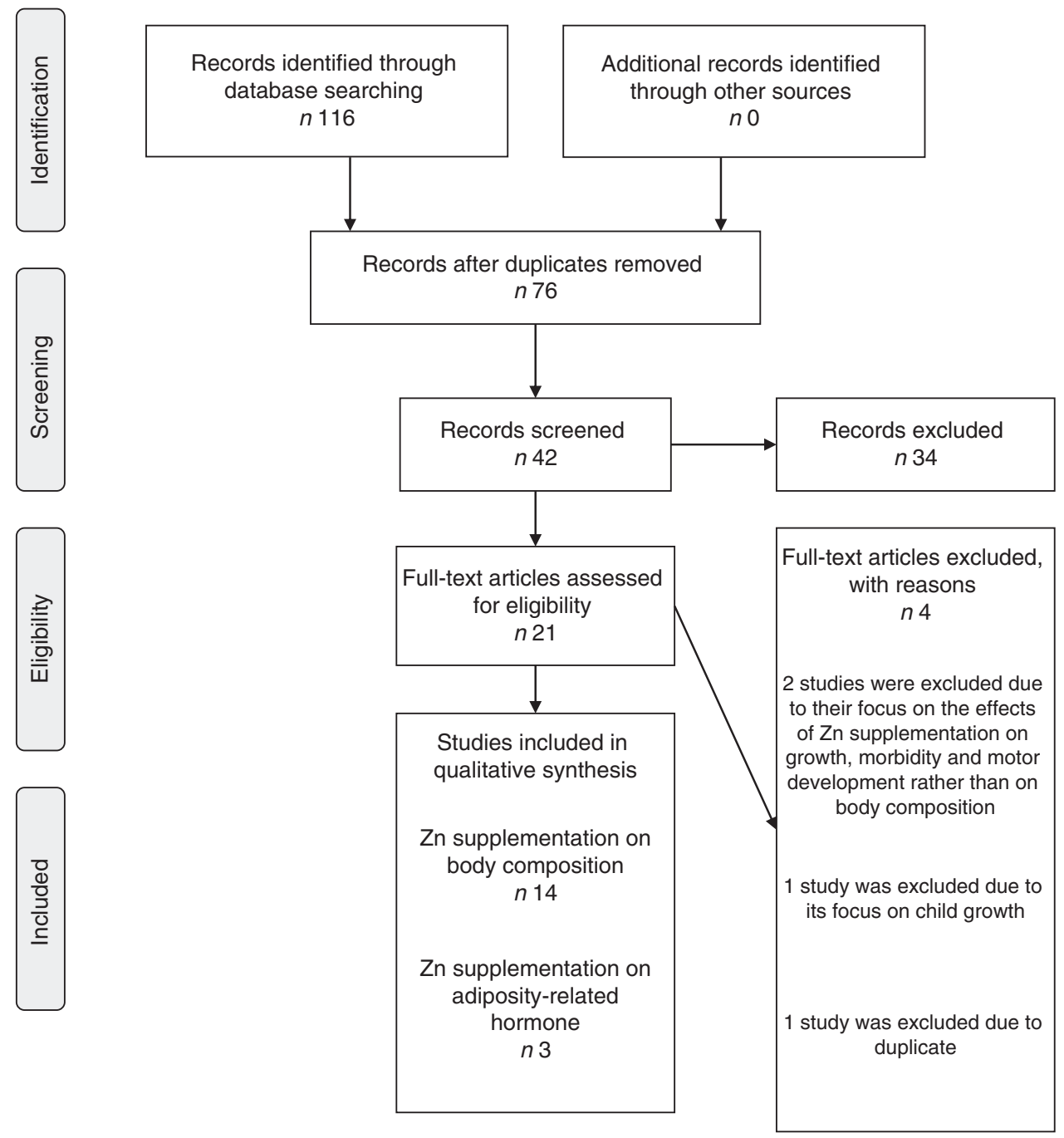

Fig. 1 Systematic review flowchart (adapted from Moher D, Liberati A, Tetzlaff J, Altman DG; The PRISMA Group (2009) Preferred Reporting Items for Systematic Reviews and Meta-Analyses: The PRISMA Statement. PLoS Med 6, e1000097. doi:10.1371/ journal.pmed1000097)

differences were found for body composition (wholebody FFM, FM and \%BF) when using DXA ${ }^{(46)}$. However, girls who received the $\mathrm{Zn}$ supplement had a significant $0.87 \mathrm{~kg}$ increase in FFM. In the study by Arsenault et $a l .{ }^{(37)}$, no effect of $\mathrm{Zn}$ supplementation was found on overall body composition among Peruvian children aged 6-8 months in 6 months. However, children with mild-to-moderate stunting (length-for-age $Z$-score $<-1 \cdot 1$ ) who received a $\mathrm{Zn}$ supplement with Fe-fortified porridge had a greater increase in FFM and increase in mean TBW compared with children in the two other groups (Fe-fortified porridge plus $\mathrm{Zn}$ and control groups). These findings suggested that $\mathrm{Zn}$ supplementation may have a beneficial effect on FFM, especially among children with pre-existing growth failure.

Seven out of the ten studies ${ }^{(37,38,42-49)}$ which reported an effect of $\mathrm{Zn}$ on body composition used only indirect measures of body composition. Friis et al. ${ }^{(44)}$ reported that Zn-supplemented children (6-17 years old) in 12 months had significantly greater increases in their MAMA-for-age $Z$-score (an indication of increased FFM) compared with children receiving the placebo. Their study also reported significant increases in weight gain while no effect was found on FM and linear growth. Rivera et $a l^{(47)}$ in their study among rural Guatemalan infants (6-9 months) found that $\mathrm{Zn}$ supplementation for 7 months was associated with an increase of $0.61 \mathrm{~cm}^{2}$ in MAMA while at the same time it increased linear growth of children who were stunted at baseline. A 15-month $\mathrm{Zn}$ supplementation trial among Gambian children aged 6 months to 2 years reported a linear increase in body weight and a very small (2\%) but significant increase in MUAC or MAMA among Zn-supplemented children ${ }^{(48)}$. Kikafunda et al. ${ }^{(45)}$ found that $\mathrm{Zn}$ supplementation among Ugandan children (aged 33-89 months) in 6 months significantly increased MUAC but had no effect on height, weight and height-for-age $Z$-score. A study carried among obese Iranian children (aged 6-10 years) in 8 weeks reported a significant 
Study location

reference

1. Philadelphia, USA; Zemel et al. ${ }^{(46)}$

Characteristics of study population

Hospital-based: prepubertal children with sickle cell disease, short stature (HAZ <2) Age: $4-10$ years

Sample size: 42

2. Canaries; Diaz-Gomez Hospital-based: preterm infants et $a .^{(38)} \quad$ Age: premature infants Sample size: 36

3. Peru; Arsenault et al. ${ }^{(37)}$ Community-based: low-income, peri-urban children with initial LAZ $<-0.5$

Age: $6-8$ months

4. Guatemala; Cavan et al. ${ }^{(43)}$

5. Zimbabwe; Friis et al. ${ }^{(44)}$

6. Uganda; Kikafunda et al. ${ }^{(45)}$

7. Guatemala; Rivera et al. ${ }^{(47)}$

8. Iran; Kelishadi et al. ${ }^{(42)}$ Clinical-based: obese children $\mathrm{BMI} \geq 95$ th percentile (CDC) Age: $6-10$ years Sample size: 60

Community-based: low-income periurban area, mild $\mathrm{Zn}$ deficiency, plant-based diet, schoolchildren Age: $6-7$ years

Sample size: 162

Community-based: rural area, generally healthy schoolchildren Age: $6-17$ years

Community-based: very low SES suburb, growth-retarded but generally healthy children Age: $33-89$ months
Sample size: 153

Community-based: infants Age: $6-9$ months Sample size: 89
Sample size: 302

Stratified by sex and initial height, randomized to receive $10 \mathrm{mg}$ $\mathrm{ZnSO}_{4} / \mathrm{d}$ in $5 \mathrm{ml}$ syrup or placebo for 12 months

\section{Data collected}

Randomization was stratified according to age sex and initial height status

$15 \%$ of the children had low $\mathrm{Zn}(<10.7 \mu \mathrm{mol} / \mathrm{l})$

Treatment group received $10 \mathrm{mg} \mathrm{ZnSO}_{4} / /$ in standard term infant formula and $0.6 \mathrm{mg} \mathrm{Cu} / \mathrm{l}$, at 36 weeks post-conceptional age, at 3 and 6 months corrected postnatal age; whereas the placebo group received the same formula without supplementation $(\mathrm{Zn}$ content $5 \mathrm{mg} / \mathrm{l}$ and $\mathrm{Cu}$ content $0.4 \mathrm{mg} / \mathrm{l})$; Fe supplement $(1 \mathrm{mg} / \mathrm{kg}$, as $\mathrm{ZnSO}_{4}$ ) was given once daily during the study period

Children were randomly assigned to one of three groups, followed for Dietary intake

6 months: (i) Zn supplement (ZnSuppl) group received Fe-fortified, wheat-based porridge without added $\mathrm{Zn}$ liquid multivitamin supplement with $3 \mathrm{mg} \mathrm{ZnSO} / / \mathrm{d}$; (ii) $\mathrm{Zn}$ fortification (ZnFort) group received the same porridge with added $\mathrm{ZnSO}_{4}$ $(3 \mathrm{mg} / \mathrm{d})$ and the liquid multivitamin supplement without $\mathrm{Zn}$ (iii) control group received porridge and liquid multivitamin supplement without $\mathrm{Zn}$ Sample size: 313

$$
\text { pplement without } \mathrm{Zn}
$$

(ame pairs by age and sex, randomized to receive $10 \mathrm{mg} \mathrm{Zn}$ table (amino acid chelate, chewable) daily or to control group for and multi-mineral

Treatment group received either $30 \mathrm{mg}$ or $50 \mathrm{mg} \mathrm{ZnSO}_{4}$ tablets (based on body weight), daily, for 12 months (equivalent to189d)

Morbidity assessment

Body composition assessed in a subset of children at baseline and 6 months using ${ }^{2} \mathrm{H}$ dilution

TBW was calculated using formula

Stratified by sex, randomized to receive $10 \mathrm{mg} \mathrm{ZnSO}_{4}$ tablet (dissolved in freshly prepared fruit juice) or placebo, $5 \mathrm{~d} /$ week for 6 months

Initial height/weight anthropometry

(hair $\mathrm{Zn}<1.68 \mu \mathrm{mol} / \mathrm{g}$ and

$\geq 1.68 \mu \mathrm{mol} / \mathrm{g}$ )

No data on morbidity and diet

Cut-off for Zn was $10.7 \mu \mathrm{mol} / \mathrm{l}$

Dietary phytic acid: $Z n$ molar ratio $=15$

Anthropometry measurements were taken at baseline and at 2, 3, 6, 7 and 8 months after the start of the trial

Double-blind intervention trial, children were assigned randomly to Maternal anthropometry receive $4 \mathrm{ml}$ of a beverage containing $10 \mathrm{mg}$ of $\mathrm{Zn}$ as $\mathrm{ZnSO}_{4}(n 45)$ Family SES

or a placebo $(n 44)$ daily $(7 \mathrm{~d} /$ week) for an average of 6.9 months. Demographic characteristics

The children's weight, length, MUAC, head circumference and TSF Morbidity

were measured at baseline and at 1- to 2-month intervals until the Dietary intake

end of supplementation. MAMA was derived from MUAC and TSF Appetite

measurements

Physical activity pattern

Compliance $95 \%$

Children were randomly assigned into two groups, received $20 \mathrm{mg}$ of Reported initial serum $\mathrm{Zn}$

elemental $\mathrm{Zn}$ or placebo. The trial was triple-masked randomized, Reported hormones related to adiposity:

followed for 8 weeks and then, after a 4-week wash-out period, the insulin, leptin

group was crossed over, so that the children initially receiving $\mathrm{Zn}$

received the placebo and vice versa; the protocol was repeated

again for 8 weeks of follow-up 
Study location; reference Characteristics of study population

9. Gambia; Bates et al. ${ }^{(48)}$ Community-based: rural children Age: $0.57-2.30$ years Sample size: 110

10. South India; Radhakrishna et al. ${ }^{(49)}$

Community-based: low-income urban

Full-term healthy infants, gestational age $<37$ weeks Sample size: 160 per group et al. ${ }^{(50)}$

Community-based: rural area, growth-stunted generally healthy pre-school children, inadequate dietary $\mathrm{Zn}$

Age: $18-36$ months

Sample size: 219

12. Ethiopia; Umeta Community-based: healthy breastet $a^{(51)}$

$$
\text { fed infants }
$$

Age: $6-12$ months

Sample size: 200

13. California, USA; Heinig Community-based: breast-fed et al. ${ }^{(52)}$

$$
\text { infants }
$$

Age: $4-10$ month

Sample size: 85
11. Mexico; Rosado

Study design

Data collected

sex, one to receive $70 \mathrm{mg} \mathrm{Zn}$ (initially as $\mathrm{Zn}$ acetate, then as $\mathrm{Zn} \quad$ Biochemical indices of $\mathrm{Zn}$ status

gluconate for better compliance) twice weekly for 1.25 years

(15 months) and the other a placebo. Growth and MUAC were

measured at weekly intervals throughout the study

Randomized, double-bind, placebo-controlled trial, community-

Nutritional status: weight, length, head circumference,

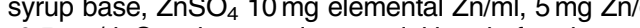
of 4 months until 18 months of age for the period of 12 months. Follow-up at $12-18$ months and 18-24 months

chest circumference, MUAC, skinfold (triceps,

biceps, subscapular) measured once in 3 month (c)

Dietary intakes in a subset of 78 children

Blood sample: $\mathrm{Zn}, \mathrm{Cu}, \mathrm{Hb}$, vitamin $\mathrm{A}$

Zn deficiency (serum Zn $<60 \mu \mathrm{g} / \mathrm{dl}$ ): $Z$ n group $26.5 \%$, supplementation group $44.1 \%$

Stratified by age and sex, ranked by height, randomized to receive Morbidity

daily: (i) $20 \mathrm{mg} \mathrm{Zn} \mathrm{(Zn} \mathrm{methionine),} \mathrm{(ii)} 20 \mathrm{mg} \mathrm{Zn}$ and $20 \mathrm{mg} \mathrm{Fe}$

(FeSO), (iii) $20 \mathrm{mg} \mathrm{Fe}$ or (iv) placebo in solution (contained sugar, citric acid, water, artificial flavour), for 12 months

$\mathrm{Hb}$, ferritin, CRP, plasma Zn (categorized into $<10.7 \mu \mathrm{mol} / \mathrm{l}$ and $\geq 10.7 \mu \mathrm{mol} / \mathrm{l})$

Initial plasma $\mathrm{Zn}$ was $>13.8 \mu \mathrm{mol} / / ; 20 \%$ of children had baseline value $<10.7 \mu \mathrm{mol} / \mathrm{l}$

A randomized, double-blind, placebo-controlled trial, 100 non-stunted Data on illness and appetite were collected daily (LAZ > - 2) were matched for age, sex and recumbent length with Samples of serum and hair for $\mathrm{Zn}$ analysis 100 randomly selected stunted $(L A Z<-2)$ infants.

$\mathrm{Zn}$ supplement ( $10 \mathrm{mg} \mathrm{Zn/d}$, as $\mathrm{ZnSO}_{4}$ ) or placebo was given $6 \mathrm{~d} /$ week for 6 months

A randomized double-blind trial comparing $\mathrm{Zn}$ supplementation $(5 \mathrm{mg} /$ Parental anthropometry $\mathrm{d}$ as $\mathrm{ZnSO}_{4}$ ) with placebo. Growth and indices of body composition Morbidity

and gross motor development were measured monthly from 3 to Dietary intake

10 months

Plasma $\mathrm{Zn}, \mathrm{Fe}, \mathrm{Cu}$, ferritin, IgG2 and IgG4

14. Santiago, Chile; Ruz Day care-based: apparently healthy Double-blind Zn supplementation trial. Children were pair-matched et al. ${ }^{(53)}$

pre-school children, from low SES conditions

Age: $27-50$ months

Sample size: 98 according to sex and age, and randomly assigned to two

Anthropometry

Morbidity

Dietary intake

$\left.10 \mathrm{mg} \mathrm{Zn/d} \mathrm{(as} \mathrm{ZnSO}_{4}\right)$ in glucose-based syrup, and the placebo Biochemical: plasma $\mathrm{Zn}, \mathrm{Cu}$ group, for 14 months

HAZ, height-for-age Z-score; LAZ, length-for-age Z-score; SES, socio-economic status; CDC, US Centers for Disease Control and Prevention; MUAC, mid upper-arm circumference; TSF, triceps skinfold; MAMA, mid upper-arm muscle area; TWB, total body water; CRP, C-reactive protein. 


\begin{tabular}{|c|c|c|c|c|}
\hline & $\begin{array}{l}\text { Study location; } \\
\text { reference }\end{array}$ & $\begin{array}{l}\text { Assessment of body } \\
\text { composition }\end{array}$ & Main findings & Body composition outcome \\
\hline 1. & $\begin{array}{l}\text { Philadelphia, USA; } \\
\text { Zemel et al. }{ }^{(46)}\end{array}$ & $\begin{array}{l}\text { Direct (DXA): FFM, } \\
\text { FM, \%BF } \\
\text { Indirect } \\
\text { (anthropometric): } \\
\text { BMI, MUAC, TSF, } \\
\text { MAFA, MAMA }\end{array}$ & $\begin{array}{l}\text { - The effect of } Z n \text { supplementation on FFM measured by DXA } \\
\text { was not significant } \\
\text { - From indirect methods: Zn supplementation had no } \\
\text { significant effect on the fat-related measures TSF, MUAFA, } \\
\text { FM and \%BF. MUAC Z-scores were significantly greater in } \\
\text { the Zn group. MAMA Z-scores were marginally significantly } \\
\text { greater in the Zn group. FFM from skinfold was not } \\
\text { significant in all samples. Only in girls, Zn supplementation } \\
\text { was shown significantly increase FFM by } 0.87 \mathrm{~kg} \\
(P=0.008) \text {. Significant increased rates of growth in height, } \\
\text { sitting height and knee height in Zn supplement group and } \\
\text { in subgroup of children whose initial height status was low } \\
\text { - No effect on BMl }\end{array}$ & $\begin{array}{l}\text { Found effect on body composition } \\
\text { Longitudinal mixed-effect models of the effect of } Z n \text { on: } \\
\text { MUAC Z-score (coefficient, SE, } P \text { value) }=0.27,0.12,0.03 \\
\text { MAMA Z-score (coefficient, SE, } P \text { value) }=0.29,0.15,0.06 \\
\text { FFM in girls only (coefficient, SE, } P \text { value) }=0.87,0.32,0.008\end{array}$ \\
\hline 2. & $\begin{array}{l}\text { Canaries; Diaz- } \\
\text { Gomez et al. }{ }^{(38)}\end{array}$ & $\begin{array}{l}\text { Direct (BIA): TBW } \\
\text { Indirect } \\
\text { (anthropometric): } \\
\text { MUAC, TSF, } \\
\text { MAFA, MAMA }\end{array}$ & $\begin{array}{l}\text { - Zn supplement had a positive effect on linear growth in } \\
\text { premature infants, at least until } 6 \text { months. Improvement in TBW } \\
\text { estimated by BIA found in the Zn group } \\
\text { - Significant interaction between the independent variables } \\
\text { (study period and group) in both length and TBW } \\
\text { - Higher mean values of TBW in the supplementation group } \\
\text { without significant differences in subcutaneous fat accretion } \\
\text { could indicate a positive effect of supplementation on fat- } \\
\text { free body mass }\end{array}$ & $\begin{array}{l}\text { Found effect on body composition } \\
\text { TBW: } \\
\text { Significant interaction between the independent variables (study period } \\
\text { and group) in TBW estimated by BIA (TBW } F(2,62)=4.59, P=0.014) \\
\text { Significant difference between supplementation and placebo group at } 3 \\
\text { and } 6 \text { moths (TBW }>0.247, P=0.01 \text { ) }\end{array}$ \\
\hline 3. & $\begin{array}{l}\text { Peru; Arsenault } \\
\quad \text { et al. }{ }^{(37)}\end{array}$ & $\begin{array}{l}\text { Direct }\left({ }^{2} \mathrm{H} \text { dilution): }\right. \\
\text { mean TBW, FFM, } \\
\text { FM, \%FM } \\
\text { Indirect } \\
\text { (anthropometric): } \\
\text { BMI, MUAC, TSF, } \\
\text { MAFA, MAMA, } \\
\text { MUAC Z-score }\end{array}$ & $\begin{array}{l}\text { - Zn supplementation, either as a liquid supplement or in fortified } \\
\text { food, did not affect overall energy intake or FFM accrual } \\
\text { compared with those who did not receive additional Zn } \\
\text { - Among the subset of children with mild-to-moderate stunting } \\
\text { (LAZ <-1.1), those who received liquid Zn supplement } \\
\text { (ZnSuppl group) had a greater increase in FFM } \\
\text { - It is possible that FFM accrual may be more sensitive to } \mathrm{Zn} \\
\text { deficiency and responds earlier to Zn supplementation than } \\
\text { linear growth } \\
\text { - TBW, FFM, FM and \%FM did not differ among groups at } \\
\text { baseline and there were no significant main effects of } \\
\text { treatment group on the change in any of these variables } \\
\text { from baseline to } 6 \text { months }\end{array}$ & $\begin{array}{l}\text { Found effect on body composition } \\
\text { Overall: } \\
\text { Mean TBW increased from } 3.97 \text { to } 4.74 \mathrm{~kg} \\
\text { FFM increased from } 4.95 \text { to } 6.00 \mathrm{~kg} \text { during the } 6 \text {-month study period } \\
(P<0.0001) \\
\text { FM increased from } 2.66 \text { to } 2.93 \mathrm{~kg}(P<0.0001) \\
\% \text { FM decreased from } 34.7 \text { to } 32.65(P=0.0002) \\
\text { Among children with } L A Z<-1.1: \\
\text { Children who received liquid } Z \mathrm{n} \text { supplement (ZnSuppl group) had a } \\
\text { greater increase in FFM }(1.36 \mathrm{~kg}) \text { than the ZnFort group (0.95 kg; } \\
P=0.02) \text { or the control group }(0.95 \mathrm{~kg} ; P=0.04)\end{array}$ \\
\hline 4. & $\begin{array}{l}\text { Guatemala; Cavan } \\
\text { et al. }{ }^{(43)}\end{array}$ & $\begin{array}{l}\text { Indirect } \\
\text { (anthropometric): } \\
\text { MUAC, TSF, } \\
\text { MAFA, MAMA }\end{array}$ & $\begin{array}{l}\text { - Children responded to the } \mathrm{Zn} \text { supplement with changes in } \\
\text { indices of body composition rather than growth } \\
\text { - The } \mathrm{Zn} \text { group had significantly higher median } \\
Z \text {-scores for MUAC and TSF at the end of the study } \\
\text { - Supplemented children showed a smaller deficit in median } \\
\text { MUAC Z-score } \\
\text { - Supplemented children showed increased in fat status, as } \\
\text { indicated by the significant rise in median TSF Z-score }\end{array}$ & $\begin{array}{l}\text { Found effect on body composition } \\
\text { MUAC Z-score (median (1st, 3rd quartile)): } \\
\text { Zn group } \\
\text { Initial }=-0.60(-0.92,-0.30) \\
\text { Final }=-0.72(-1.05,-0.26) \\
\quad \text { Change }=-0.03(-0.30,0.16), P<0.05 \\
\text { Placebo } \\
\quad \text { Initial }=-0.44(-0.86,-0.19) \\
\text { Final }=-0.66(-1.08,-0.35) \\
\text { Change }=-0.20(-0.42,0.02), P<0.05 \\
T S F \text {-score (median }(1 s t, 3 \text { rd quartile)): } \\
\text { Zn group } \\
\text { Initial }=-0.20(-0.50,0.10) \\
\text { Final }=0.33(-0.07,0.95) \\
\quad \text { Change }=0.50(0.25,0.99), P<0.05\end{array}$ \\
\hline
\end{tabular}


Table 2 Continued

Study location; $\quad$ Assessment of body

reference composition

Main findings

5. Zimbabwe; Friis et al. ${ }^{(4)}$

Indirect (anthropometric): MUAC, TSF,

6. Uganda; Kikafunda et al. ${ }^{(4)}$

Indirect

(anthropometric)

MUAC,

MAMA
- Significance effects on weight, WAZ and MAMA-for-age Zscore over 3 months but no effects over 12 months

- Zn supplementation had favourable effects on lean body mass and weight gain, but no effects on fat and

linear growth

- The mean weight gain was $0.51 \mathrm{~kg}$ in the $\mathrm{Zn}$-supplemented group $v .0 .14 \mathrm{~kg}$ in the placebo group $(P=0.01)$

- The change in MAMA-for age Z-score was significantly larger among $\mathrm{Zn}$-supplemented children compared with children receiving placebo $(0.10 \mathrm{v} .0 .001, P=0.03)$

- No effect on height, weight and HAZ

- Zn supplementation had a significant effect on MUAC $(P=0.029)$

- Greater weight gain only in children from medium SES

- Significantly increased MUAC $(P=0.03)$

7. Guatemala; Rivera Indirect (anthropometric)

MAFA, MAMA

8. Iran; Kelishad et al. ${ }^{(42)}$
Indirect
- Zn supplementation was associated with an overall increase of $0.61 \mathrm{~cm}^{2}$ in MAMA $(P<0.001)$

- Children who received $\mathrm{Zn}$ supplements had a mean length increment that was $0.75 \mathrm{~cm}$ greater than those who did not $(P=0.12)$

- There was a significant interaction between treatment group and initial LAZ $(P=0.04)$, such that supplemented children who were stunted at baseline $(L A Z<-2)$ gained $1.40 \mathrm{~cm}$ more than stunted children who received the placebo

- Zn supplementation increased accretion of FFM and enhanced the linear growth of those who were stunted at baseline

- In both groups, mean BMI Z-scores remained high afte receiving $\mathrm{Zn}$ supplementation. Mean weight decreased significantly $(P=0.01)$. Mean BMI $(P=0.01)$ and $\mathrm{BMI}$ $Z$-score $(P=0.02)$ decreased significantly and these values increased after receiving placebo
BM
Body composition outcome

\section{Placebo}

Initial $=-0.27(-0.57,0.03)$

Final $=0.14(-0.16,0.43)$

Change $=0.38(0.18,0.66), P<0.05$

Found effect on body composition

MAMA-for-age $Z$-score $(P=0.03)$ :

Zn group

Baseline $($ mean $(\mathrm{SD}))=-0.92(0.59)$

At 3 months $($ mean $(95 \% \mathrm{Cl}))=0.10(0.04,0.15)$

Placebo

Baseline $($ mean $(\mathrm{sD}))=-0.85(0.58)$

At 3 months (mean $(95 \% \mathrm{Cl}))=0.01(-0.05,0.07)$

Found effect on body composition

MUAC (mean (SD), in $\mathrm{mm})(P=0.03)$ :

Zn group

Baseline $=163.9(11.6)$

SM changes

At 3 months $=-0.88(0.42)$

At 8 months $=0.86(0.57)$

lacebo

Baseline $=165.9(11.1)$

LSM changes

At 3 months $=-1.25(0.42)$

Found effect on body composition

MAMA (mean (sD), in $\mathrm{cm}^{2}$ ):

Zn group

Baseline $=9.9(1.8)$

Final $=11.1(1.8)$

Difference $=1.2(1.7)$

Placebo

Baseline $=10.0(2 \cdot 1)$

Final $=10.6(1.6)$

Difference $=0.6(1.9)$

Main effect of multiple regression models of treatment for MAMA

Coefficient of regression $=0.17, P=0.0002$

Found effect on body composition

(i) Children receiving $\mathrm{Zn}$ supplementation followed

by placebo

BMI (mean (SD), in $\left.\mathrm{kg} / \mathrm{m}^{2}\right)(P=0.01)$ :

Zn group

Before $=25.05$ (3.70), $P<0.05$ (after $v$. before receiving $Z n$ ) After $=23.29$ (3.64), $P<0.05$ (after $v$. before receiving $Z n$ )

Placebo group Before $=23.21(3.28), P<0.05$ (after $v$. before receiving placebo)
After $=24.87(3.40), P<0.05$ (after $v$. before receiving placebo) 
BMI Z-score (mean (SD)) $(P=0.02)$ :

Zn group

Before $=3.00(0.41), P<0.05$ (after $v$. before receiving $Z n$ ) After $=2.50(0.42), P<0.05$ (after $v$. before receiving $Z n$ )

Placebo group

Before $=2.50$ (0.37), $P<0.05$ (after $v$. before receiving placebo)

After $=3.00(0.45), P<0.05$ (after $v$. before receiving placebo)
(ii) Children receiving placebo followed by $\mathrm{Zn}$ supplement

$B M I$ (mean $(s D)$, in $\left.\mathrm{kg} / \mathrm{m}^{2}\right)(P=0.03)$ :

Zn group

Before $=24.71(3.70), P<0.05$ (after $v$. before receiving placebo)

After $=25.19(3.64), P<0.05$ (after $v$. before receiving placebo)

Placebo group

Before $=25.28$ (3.27), $P<0.05$ (after $v$, before receiving $Z n$ )

After $=23.75(3.40), P<0.05$ (after $v$. before receiving $Z n$ )

$B M I$-score (mean (SD)) $(P=0.01)$ :

Zn group

Before $=3.00(0.38)$

After $=3.00(0.46)$

Before $=3.00(0.42)$

Before $=3.00(0.42)$
After $=2.50(0.37)$

9. Gambia; Bates et $a .^{(4)}$

10. South India; Radhakrishna
Indirect

(anthropometric):

MAFA, MAMA

Indirect

(anthropometric):

skinfold thickness

at triceps, biceps,

subscapular
- Body weight and arm circumference showed a linear increase

- For body weight there was no significant overall effect of the

supplement

- For arm circumference, a very small $(2 \%)$ but significant

$(P<0.01)$ difference favoured the supplemented group

- Skinfold thicknesses taken at three sites showed a significan increase in SSF and TSF at 18,21 and 24 months when compared with baseline
Found effect on body composition

MUAC (mean (SE), in $\mathrm{mm}$ ):

Unsupplemented group

1st assessment $=137(1.4)$

2nd assessment $=145(1.3)$

Change $=7.7(1.4)$

Zn group

1st assessment $=133(1.6)$

2nd assessment $=143(1.5)$

Change $=8.7(1.0)$

\section{Found effect on body composition}

At 18 and 21 months age, SSF was significantly $(P=0.022$ and $P=0.033)$ higher in the $\mathrm{Zn}$ group compared with the placebo group by mean of $0.331(\mathrm{Cl} 0.049,0.613) \mathrm{cm}$ and $0.318(\mathrm{Cl} 0.025,0.611) \mathrm{cm}$ TSF:

At 21 and 24 months, TSF was significantly $(P=0.011$ and $P=0.024)$ higher in the $\mathrm{Zn}$ group compared with the placebo group by mean of $0.425(\mathrm{Cl} 0.095,0.755) \mathrm{cm}$ and $0.389(\mathrm{Cl} 0.047,0.731) \mathrm{cm}$

DXA, dual-energy X-ray absorptiometry; FFM, fat-free mass; FM, fat mass; \%BF, percentage body fat; MUAC, mid upper-arm circumference; TSF, triceps skinfold; MAFA, mid upper-arm fat area; MAMA, mid upper-arm muscle area; BIA, bio-impedance analysis; TBW, total body water; \%FM, percentage fat mass; LAZ, length-for-age Z-score; WAZ, weight-for-age Z-score; HAZ, height-for-age Z-score; SES, socio-economic status; SSF, subscapular skinfold; SE, standard estimate; LSM, least-square mean. 
decrease in mean weight and mean BMI and BMI $Z$-score, respectively, after $\mathrm{Zn}$ supplementation ${ }^{(42)}$. In a study carried out in peri-urban communities of Guatemala, Cavan et al. ${ }^{(43)}$ reported that primary-school children aged 6-7 years supplemented with Zn for 6 months had significantly increased median triceps skinfold $Z$-score (a measure of fat status) but a small decrease in median MUAC Z-score. Radhakrishna et al. ${ }^{(49)}$ reported that $\mathrm{Zn}$ supplementation of full-term normal infants ( $<37$ weeks) for a mean period of $190 \mathrm{~d}$ had significant effect on skinfold thicknesses, but not on linear growth.

The four studies that found no significant effect of supplementation on measures of body composition were carried out in very different settings; all of them used indirect measures of body composition (Table 3). Rosado et $\mathrm{al}^{(50)}$ reported the lack of effect of a 12-month $\mathrm{Zn}$ supplementation among Mexican children (18-36 months) on anthropometry measurements. A study in Ethiopia carried out by Umeta et $a l .{ }^{(51)}$ found that Zn supplementation among children aged 6-12 months for 6 months did not have any measurable effects on body composition although it increased the length of stunted infants. Heinig et $a l .{ }^{(52)}$ found no effect of $\mathrm{Zn}$ on anthropometric indices among breast-fed infants (4-10 months) followed for 10 months. Similarly, Ruz et al. ${ }^{(53)}$ reported no effect of Zn supplementations on body composition among pre-school children (aged 27-50 months) followed for 14 months, although there was a significant trend for increased MAMA among supplemented boys.

Three studies concerned with the effect of $\mathrm{Zn}$ supplementation on adiposity-related hormone levels were included in the present review (Table 4). Kelishadi et $a l .{ }^{(42)}$ found that supplementing children (aged 6-10 years) with $20 \mathrm{mg} \mathrm{Zn} / \mathrm{d}$ in 8 weeks was associated with significantly reduced serum leptin and insulin. In contrast, Arsenault et al. ${ }^{(40)}$ found no effect on plasma leptin, ghrelin and insulin concentrations among 6-monthold children supplemented with $3 \mathrm{mg} \mathrm{ZnSO}_{4} / \mathrm{d}$ in 7 months. The third study by Bueno et al. ${ }^{(41)}$ found no effect of Zn supplementation for 6 months on serum leptin concentrations among newborns with intra-uterine growth retardation and asymmetric growth retardation. Interestingly, serum leptin concentrations correlated significantly with changes in skinfold measurements and weightfor-age $Z$-score among children in the placebo group. There was no clear association between $\mathrm{Zn}$ formulation and its dosage on hormonal levels from those three studies.

\section{Discussion}

The present systematic review of the effects of $\mathrm{Zn}$ supplementation on childhood body composition can only be inconclusive at this point due to the small number of trials and their diverse study designs. There is evidence that Zn supplementation overall has an effect on body composition when determined by anthropometric measurements, i.e. increased $\operatorname{MUAC}^{(43,45,46,48)}$, $\operatorname{TSF}^{(43,49)}$, subscapular skinfold ${ }^{(49)}$ and MAMA ${ }^{(44,46,47)}$, and decreased $\mathrm{BMI}^{(42)}$. Zn supplementation also showed an effect on body composition when measured by a direct method: i.e. increased mean values of TBW estimated by $\operatorname{BIA}^{(37,38)}$, especially among children with mild-to-moderate stunting ${ }^{(37)}$; increased FFM estimated by $\mathrm{TBW}^{(37)}$; and increase in FFM assessed by DXA in girls who received the $\mathrm{Zn}$ supplement ${ }^{(46)}$. Only one study ${ }^{(42)}$ found that $\mathrm{Zn}$ supplementation was associated with reduced serum leptin and insulin. Thus, $\mathrm{Zn}$ supplementation may have a beneficial effect on body composition, especially on FFM among children with pre-existing growth failure.

These findings suggest that the effect of $\mathrm{Zn}$ supplementation on body composition may be less consistent than its effect on growth. Three previously published meta-analyses of $\mathrm{Zn}$ supplementation trials on growth have reported strong evidence of the growth-limiting effect of Zn deficiency ${ }^{(25,54,55)}$. Zn directly influences the growth hormone and insulin-like growth factor-I systems $^{(56)}$, affects bone metabolism ${ }^{(57)}$ and is involved in DNA synthesis, all of which may affect linear growth ${ }^{(58)}$. However, the effect of $\mathrm{Zn}$ supplementation on body composition may depend on the pre-existing nutritional status of children. The study by Arsenault et al. ${ }^{(37)}$ suggests that pre-existing Zn deficiency may be contributing to the development of obesity via its relationship with fat deposition associated with childhood stunting.

It is not clear whether the observed changes of body composition resulted from changes in FM or FFM and whether stunted children are at greater risk of obesity as a result of such changes, since only a few studies reported the findings for FFM and $\mathrm{FM}^{(37,46)}$ from direct measures and most of the studies used the anthropometric method in determining body composition. However, $\mathrm{Zn}$ is essential for lean body mass synthesis and its deficiency was reported to increase the energy cost of tissue deposition $^{(18)}$. Zn deficiency may also cause altered fatty acid metabolism leading to an increase in $\mathrm{FM}^{(18,26)}$. It is important, therefore, to concurrently study how the effect of $\mathrm{Zn}$ supplementation on body fat or FFM relates to its effect on linear growth.

Reduced $\mathrm{Zn}$ absorption and bioavailability, the combination of $\mathrm{Zn}$ with other micronutrients and the form by which $\mathrm{Zn}$ is delivered may be determining the efficacy of $\mathrm{Zn}$ on body composition ${ }^{(59)}$. Zn and Fe, for example, compete for mucosal binding sites as well as in the absorption process ${ }^{(60)}$. Dietary Fe:Zn greater than 2:1 will inhibit $\mathrm{Zn}$ absorption, as the Fe carrier, transferrin, which also carries $\mathrm{Zn}$, becomes saturated ${ }^{(61)}$. $\mathrm{Zn}$ is absorbed most effciently from aqueous solutions when $\mathrm{Zn}$ is in solution form, but not when it is part of a complex meal ${ }^{(62)}$. Zn-fortified foods generally produce a small reduction in fractional absorption, although a positive impact on net absorption ${ }^{(63)}$. 
Table 3 Studies that did not find any effect of zinc supplementation on body composition

\begin{tabular}{|c|c|c|c|}
\hline & $\begin{array}{l}\text { Study location; } \\
\text { reference }\end{array}$ & $\begin{array}{l}\text { Methods of body composition } \\
\text { assessment }\end{array}$ & Main finding \\
\hline 1. & $\begin{array}{l}\text { Mexico; Rosado } \\
\text { et al. }{ }^{(50)}\end{array}$ & $\begin{array}{l}\text { Indirect (anthropometric): BMI, } \\
\text { MUAC, TSF, MAFA, MAMA }\end{array}$ & $\begin{array}{l}\text { Did not find effect on body composition } \\
\text { - Zn and } \mathrm{Zn}+\text { Fe supplements reduced morbidity but had no effect on growth and/ } \\
\text { or body composition } \\
\text { - No effect of } \mathrm{Zn} \text { perhaps due to the children not being severely stunted or } \mathrm{Zn} \\
\text { deficient and the small sample size in each treatment group }\end{array}$ \\
\hline 2. & $\begin{array}{l}\text { Ethiopia; Umeta } \\
\quad \text { et al. }{ }^{(51)}\end{array}$ & $\begin{array}{l}\text { Indirect (anthropometric): BMI, } \\
\text { MUAC, TSF, MAFA, MAMA }\end{array}$ & $\begin{array}{l}\text { Did not find effect on body composition } \\
\text { - The length (mean (SE)) of stunted infants increased significantly more }(P<0.001) \\
\text { when supplemented with } \mathrm{Zn}(7.0(1.1) \mathrm{cm}) \text { than with placebo }(2.8(0.9) \mathrm{cm}) ; \text { and } \\
\text { the effect was greater }(P<0.01) \text { than in non-stunted infants }(6.6(0.9) \mathrm{v} .5 .0(0.8) \\
\mathrm{cm} \text { for the } \mathrm{Zn} \text { and placebo groups respectively, } P<0.01) \\
\text { - Zn supplementation also increased the weight (mean }(\mathrm{SE})) \text { of stunted children } \\
(1.73(0.39) v .0 .95(0.39) \mathrm{kg} \text { for the corresponding placebo group, } P<0.001) \text { and } \\
\text { of non-stunted children }(1.19(0.39) v .1 .02(0.32) \mathrm{kg} \text { for the corresponding } \\
\text { placebo group, } P<0.05) \\
\text { - TSF and MUAC did not change, suggesting that the supplementation period was } \\
\text { too short to find any measurable effects on body composition }\end{array}$ \\
\hline 3. & $\begin{array}{l}\text { California, USA; } \\
\text { Heinig et al. }{ }^{(52)}\end{array}$ & $\begin{array}{l}\text { Indirect (anthropometric): BMI, } \\
\text { MUAC, TSF, MAFA, MAMA }\end{array}$ & $\begin{array}{l}\text { Did not find effect on body composition } \\
\text { - The baseline characteristics, attained weight or length at } 10 \text { months, growth } \\
\text { velocity, gross motor development and morbidity did not differ significantly } \\
\text { between groups, even after controlling for potentially confounding variables }\end{array}$ \\
\hline 4. & $\begin{array}{l}\text { Santiago, Chile; } \\
\text { Ruz et al. }{ }^{(53)}\end{array}$ & $\begin{array}{l}\text { Indirect (anthropometric): BMI, } \\
\text { MUAC, TSF, MAFA, MAMA }\end{array}$ & $\begin{array}{l}\text { Did not find effect on body composition } \\
\text { - Height gain after } 14 \text { months was on average } 0.5 \mathrm{~cm} \text { higher in the supplemented } \\
\text { group }(P=0.10) \\
\text { - Boys from the supplemented group gained } 0.9 \mathrm{~cm} \text { more than those in the placebo } \\
\text { group }(P=0.045) \text {. No effect was seen in girls } \\
\text { - Although no significant differences were observed in the rest of the variables } \\
\text { studied, trends }(0.05<P<0.10) \text { in the supplemented group compared with the } \\
\text { placebo group for increased MAMA in boys }(P=0.08) \text {, improved response to } \\
\text { tuberculin and reduced rates of parasite re-infestation were noted }\end{array}$ \\
\hline
\end{tabular}

MUAC, mid upper-arm circumference; TSF, triceps skinfold; MAFA, mid upper-arm fat area; MAMA, mid upper-arm muscle area; SE, standard estimate.

The study by Arsenault et al. $^{(37)}$ included $\mathrm{Zn}$ in a liquid multivitamin supplement and in a wheat-based, Fe-fortified porridge, both of which could reduce $\mathrm{Zn}$ absorption.

Zn status can have an effect on adipokines and other hormones involved in adipogenesis which can determine body composition and risk of obesity. The adipokine leptin that is produced primarily in adipose tissue regulates food intake and energy expenditure ${ }^{(64)}$ and is positively associated with body weight ${ }^{(65)}$, BMI, \%BF and FM among children ${ }^{(66,67)}$. Zn deficiency leads to reduced serum leptin concentration in rats ${ }^{(68)}$ and $\operatorname{man}^{(69)}$, and reduced leptin secretion by rat adipocytes while repletion reversed this effect ${ }^{(70)}$. However, two of the three studies that examined the effect of $\mathrm{Zn}$ on adipokines and other hormones involved in adipogenesis found no clear effect.

A child's overall adiposity may contribute to this lack of an effect of $\mathrm{Zn}$ on leptin and subsequently body composition, since leptin levels reflect the amount of energy stored in somatic adipose tissue in man and other mammals ${ }^{(71,72)}$ and are highly correlated with body fat in both adults and children ${ }^{(73,74)}$. Sex may also modify the effect of $\mathrm{Zn}$ on leptin since studies have reported that women have markedly higher leptin concentrations than men for any given degree of $\mathrm{FM}^{(75)}$ and this may be present at birth $^{(76)}$. In addition, infection and/or inflammation may alter the effect of $\mathrm{Zn}$ on leptin since the induction of leptin is part of the acute-phase response to inflammatory stimuli such as lipopolysaccharide and pro-inflammatory cytokines ${ }^{(77)}$.

\section{Sources of study outcome beterogeneity}

There were important differences between studies in factors that may have modified associations between Zn supplementation and body composition and so contributed to the inconsistent findings. Most importantly, methods used in measuring body composition varied between the different studies. All of the Zn supplementation studies included in the present review used anthropometry as indirect measures to determine body composition while only three studies used more direct methods such as DXA, BIA and ${ }^{2} \mathrm{H}$ dilution in assessing body composition ${ }^{(37,38,46)}$. Anthropometric methods have poor accuracy and precision when used alone and so have reduced utility for predicting body adiposity outcomes compared with direct methods ${ }^{(36)}$. The direct method of body composition assessment is more ideal where the aim is to quantify FM or FFM with greater accuracy ${ }^{(36)}$.

The initial nutritional status of children varied between the different studies and so may have modified the effects of $\mathrm{Zn}$ supplementation. An effect on body composition 
Table 4 Zinc supplementation studies on adiposity-related hormonal levels

\begin{tabular}{|c|c|c|c|c|c|}
\hline & $\begin{array}{l}\text { Study location; } \\
\text { reference }\end{array}$ & Characteristics of study population & Study design & Data collected & Finding \\
\hline 1. & Peru; Arsenault et al. ${ }^{(40)}$ & $\begin{array}{l}\text { Community-based: low-income, } \\
\text { peri-urban communities, LAZ } \\
<-0.5 \\
\text { Age: } 5-7 \text { months } \\
\text { Sample size: } 142\end{array}$ & $\begin{array}{l}\text { Children were randomly assigned } \\
\text { to one of three groups, followed } \\
\text { for } 7 \text { months: (i) } \mathrm{Zn} \text { supplement } \\
\text { group received Fe-fortified, } \\
\text { wheat-based porridge without } \\
\text { added } \mathrm{Zn} \text { liquid multivitamin } \\
\text { supplement with } 3 \mathrm{mg} \mathrm{ZnSO}_{4} / \mathrm{d} \text {; } \\
\text { (ii) } \mathrm{Zn} \text { fortification group } \\
\text { received the same porridge with } \\
\text { added } \mathrm{ZnSO} \mathrm{S}_{4}(3 \mathrm{mg} / \mathrm{d} \text { ) and the } \\
\text { liquid multivitamin supplement } \\
\text { without } \mathrm{Zn} \text {; (iii) control group } \\
\text { received porridge and liquid } \\
\text { multivitamin supplement without } \\
\mathrm{Zn}\end{array}$ & $\begin{array}{l}\text { Anthropometric measurements } \\
\text { Body composition (TBW) } \\
\text { Plasma hormone (ghrelin, } \\
\text { insulin, leptin) and glucose } \\
\text { concentrations } \\
\text { Dietary intake before } \\
\text { supplementation }\end{array}$ & $\begin{array}{l}\text { Did not find effect on hormone } \\
\text { - Supplemental Zn did not } \\
\text { affect the children's growth } \\
\text { anthropometric indices or } \\
\text { plasma hormone } \\
\text { concentrations }\end{array}$ \\
\hline 2. & Spain; Bueno et al. ${ }^{(41)}$ & $\begin{array}{l}\text { Hospital-based: gestational age } \\
38-41 \text { weeks, birth weight } \\
<10 \text { th percentile for gestational } \\
\text { age and ponderal index }<2 \cdot 4 \\
\text { Gestational age: } 38-41 \text { weeks } \\
\text { Sample size: } 31\end{array}$ & $\begin{array}{l}\text { Treatment group received } 3 \mathrm{mg} \\
\mathrm{ZnSO}_{4} / \mathrm{d} \text { in } 3 \mathrm{ml} \text { syrup/d, } \\
\text { followed for } 6 \text { months }\end{array}$ & $\begin{array}{l}\text { Anthropometric data: weight, } \\
\text { length, ponderal index, head } \\
\text { and arm circumferences, } \\
\text { skinfold } \\
\text { Hb, IGF-I, IGFBP-3 } \\
\text { Hair Zn }\end{array}$ & $\begin{array}{l}\text { Did not find effect on hormone } \\
\text { Changes in serum leptin } \\
\text { concentrations showed } \\
\text { significant correlation with } \\
\text { changes in sum of four } \\
\text { skinfolds and weight-for-age } \\
Z \text {-score, only in the } \\
\text { placebo group }\end{array}$ \\
\hline 3. & Iran; Kelishadi et al. ${ }^{(42)}$ & $\begin{array}{l}\text { Clinical-based: obese children, } \\
\text { BMI } \geq 95 \text { th percentile (CDC) } \\
\text { Age: } 6-10 \text { years } \\
\text { Sample size: } 60\end{array}$ & $\begin{array}{l}\text { Children were randomly assigned } \\
\text { into two groups, received } 20 \mathrm{mg} \\
\text { of elemental Zn or placebo. The } \\
\text { trial was triple-masked } \\
\text { randomized, followed for } \\
8 \text { weeks and then, after a } 4- \\
\text { week wash-out period, the } \\
\text { groups were crossed over, so } \\
\text { that the children initially } \\
\text { receiving Zn received the } \\
\text { placebo and vice versa, the } \\
\text { protocol was repeated again for } \\
8 \text { weeks of follow-up }\end{array}$ & $\begin{array}{l}\text { Anthropometry: weight, BMI, } \\
\text { BMI Z-score, WC } \\
\text { Reported initial Zn status } \\
\text { Reported hormone-related to } \\
\text { adiposity: Insulin, leptin } \\
\text { No report about diet and } \\
\text { morbidity }\end{array}$ & $\begin{array}{l}\frac{\text { Found effect on hormone }}{\text { (insulin and leptin) }} \\
\text { - In both groups, significant } \\
\text { decrease was reported for } \\
\text { leptin after receiving } \mathrm{Zn}, \\
\text { without significant change } \\
\text { after receiving placebo } \\
\text { - In both groups: hs-CRP and } \\
\text { markers of IR decreased } \\
\text { significantly after receiving } \\
\text { Zn, but increased after } \\
\text { receiving placebo }\end{array}$ \\
\hline
\end{tabular}

LAZ, length-for-age Z-score; CDC, US Centers for Disease Control and Prevention; TBW, total body water; IGF-I, insulin-like growth factor-I, IGFBP-3, insulin-like growth factor binding protein-3; WC, waist circumference; hs-CRP, high-sensitivity C-reactive protein; IR, insulin resistance. 
was found in three ${ }^{(45-47)}$ of the six studies where study subjects were growth stunted ${ }^{(37,45,47,50,51)}$ and in children with sickle cell disease whose stature was below $2 \mathrm{sD}{ }^{(46)}$. The study by Arsenault $e t \mathrm{al}^{(37)}$ did not find an overall effect of $\mathrm{Zn}$ supplementation on FFM but did find an increase in FFM among mild-to-moderately stunted children (length-for-age $Z$-score $<-1 \cdot 1$ ). Interestingly, this finding suggests that a positive response to $\mathrm{Zn}$ supplementation of body composition is more likely to be apparent among children with pre-existing growth failure. Diaz-Gomez et al. ${ }^{(38)}$ found an improvement in TBW among premature infants in the $\mathrm{Zn}$ group (birth weight between 1000 and $2500 \mathrm{~g}$ ). Two of four studies conducted among generally healthy normal children also found a positive effect of $\mathrm{Zn}$ supplementation on lean body mass $^{(44)}$ and a very small but significant increase in MUAC Or MAMA ${ }^{(48)}$.

It is not clear whether children's initial Zn status and serum adipokine concentrations may also have modified the effect of $\mathrm{Zn}$ supplementation on body composition. One ${ }^{(43)}$ out of two studies ${ }^{(43,50)}$ where children had a high initial $\mathrm{Zn}$ status $(>13.5 \mu \mathrm{mol} / \mathrm{l})$ reported an effect of $\mathrm{Zn}$ supplementation on body composition; while an effect was also found in three studies among children with low initial $\mathrm{Zn}$ status ${ }^{(42,44,46)}$. The studies concerned with the effect of $\mathrm{Zn}$ on adiposity-related hormones did report the initial Zn status of children but did not consistently report on the initial hormone levels.

The inclusion of other micronutrients in the control group may also contribute to the inconsistent findings. Five studies compared the effect of $\mathrm{Zn}$ supplementation on body composition with the effects produced with multimicronutrients ${ }^{(37,38,43,49,50)}$ while nine studies compared $\mathrm{Zn}$ with a placebo group. The supplementation regimen for the treatment groups in two studies ${ }^{(37,40)}$ was a wheat-based, Fe-fortified porridge and a liquid multivitamin. Zn supplementation was found to have an effect on body composition (increase in FFM) among the subset of children with mildto-moderate stunting. In the study by Cavan et $a l^{(43)}$, significantly higher median $Z$-scores for MUAC and TSF were found in the $\mathrm{Zn}$-supplemented group when children in both the $\mathrm{Zn}$ and placebo groups were provided with multi-micronutrient supplements. In contrast, $\mathrm{Zn}$ and $\mathrm{Zn}$ plus Fe supplements had no effect on growth and/or body composition in the study by Rosado et al. ${ }^{(50)}$. Diaz-Gomez et al. ${ }^{(38)}$ reported an improvement in TBW among children in the Zn group fed with a standard term formula supplemented with Zn (final content: $10 \mathrm{mg} / \mathrm{l}$ ) and a small quantity of $\mathrm{Cu}$ (final content: $0.6 \mathrm{mg} / \mathrm{l}$ ); the placebo group received the same formula without supplementation (final content of $\mathrm{Zn}: 5 \mathrm{mg} / \mathrm{l}$; final content of $\mathrm{Cu}: 0.4 \mathrm{mg} / \mathrm{l}$ ), and an Fe supplement was given to all children once daily during the study period. These findings suggest that combining micronutrients may dilute the effects of $\mathrm{Zn}^{(59)}$. A trial that supplemented Chinese obese women with Zn combined with other micronutrients did report reductions in body weight, BMI and abdominal obesity and improvement in serum lipid profiles ${ }^{(8)}$.

Children's age and sex may be a source of heterogeneity in findings. For example, two studies ${ }^{(43,44)}$ conducted among school-aged children found an effect of Zn supplementation while one study ${ }^{(45)}$ reported an effect among pre-school children. Studies that included infants $^{(38)}, 5-7$-month-old children ${ }^{(37)}$ and 4-10-year-old children $^{(46)}$ found no effect. The modification of $\mathrm{Zn}$ supplementation effect on hormone levels by age is difficult to determine since there were only limited studies of $\mathrm{Zn}$ supplementation on adiposity-related hormone levels ${ }^{(40-42)}$. There are significant sex differences in body composition before the onset of puberty. Prepubertal girls generally have higher total body fat and \%BF but lower $\mathrm{FFM}^{(78)}$ than do boys matched for age, weight and height. Fat distribution also differs between sexes, with prepubertal girls generally having greater trunk fat than do boys ${ }^{(79)}$. Thus, the pattern of the effect of $\mathrm{Zn}$ supplementation on body composition might not be consistent if studies have children of different age groups. In certain age ranges children might have different impacts by $\mathrm{Zn}$ supplementation on body composition.

The formulation, dosage and duration of $\mathrm{Zn}$ supplementation may also have contributed to the inconsistencies in the effect of $\mathrm{Zn}$, since these varied considerably between the different studies. An effect of $\mathrm{Zn}$ on body composition was found in seven studies when $\mathrm{ZnSO}_{4}$ was used as a supplement. Studies that used $\mathrm{Zn}$ as an amino acid chelate ${ }^{(43)}$, elemental $\mathrm{Zn}^{(42)}$, and $\mathrm{Zn}$ acetate and $\mathrm{Zn}$ gluconate ${ }^{(48)}$ also showed an effect. The dosages of $\mathrm{Zn}$ supplementation varied considerably (from 3 to $70 \mathrm{mg} / \mathrm{d}$ ) between the different studies. Dosages of $10 \mathrm{mg} / \mathrm{d}$ given to school-aged children ${ }^{(43)}, 10 \mathrm{mg} / \mathrm{d}$ given to pre-school children ${ }^{(45)}$ and 30 and $50 \mathrm{mg} / \mathrm{d}$ given to schoolchildren whose weight was below $29.5 \mathrm{~kg}$ and $\geq 29.5 \mathrm{~kg}$, respectively ${ }^{(44)}$, all had effects on body composition. Studies that gave $20 \mathrm{mg} \mathrm{Zn} / \mathrm{d}$ to pre-school children, $10 \mathrm{mg} \mathrm{Zn/d}$ to school-aged children ${ }^{(46)}$ and $10 \mathrm{mg} \mathrm{Zn/d}$ to infants ${ }^{(38)}$ found no effect on body composition. Another study by Arsenault et al. ${ }^{(37)}$, which supplemented children with $3 \mathrm{mg} \mathrm{Zn} / \mathrm{d}$ (either in liquid supplement or fortified porridge), showed no effect. Four studies ${ }^{(38,43,45,47)}$ which supplemented children with $\mathrm{Zn}$ for 6-7 months and three studies ${ }^{(44,46,48)}$ which supplemented children with $\mathrm{Zn}$ for 10-15 months reported an effect on body composition. The findings suggest that at least 6 months of $\mathrm{Zn}$ supplementation can have an effect on body composition but differing dosages and the formulation of $\mathrm{Zn}$ have no clear association with body composition.

Additional sources of heterogeneity that may modify study outcomes are dietary $\mathrm{Zn}$ intake, dietary factors influencing $\mathrm{Zn}$ absorption and morbidity/illness. Although the influence of diet and morbidity were not adequately tested in the reviewed analyses, ten studies ${ }^{(37,38,44-48,51-53)}$ 
carried out dietary data collection to determine mean daily intakes of energy, protein, $\mathrm{Zn}^{(44-46)}$, phytic acid ${ }^{(45)}$ and $\mathrm{Cu}^{(38)}$. In addition, the children were generally selected from low socio-economic areas ${ }^{(44,45,47-49)}$ in which $\mathrm{Zn}$ deficiency prevalence is usually high due to poor dietary intake. Only one study ${ }^{(40)}$ concerned with the effect of $\mathrm{Zn}$ supplementation on adipokines measured the dietary intake of $\mathrm{Zn}$ and the relative content of phytic acid to $\mathrm{Zn}$ in ingested food, although it was reported in another paper ${ }^{(37)}$ that reported the body composition results.

Another source of outcome heterogeneity was compliance. For example, the study by Cavan et al..$^{(43)}$ had a low average number of treatment days because of children's frequent absences from school. Zn supplementation was administered only on school days in the studies by Friis et $a l^{(44)}$ and Kikafunda et al. ${ }^{(45)}$, resulting in sporadic intake. Similarly, the mild effect of Zn supplementation on MUAC reported by Kikafunda et $a l .{ }^{(45)}$ may partly result from high study attrition and low compliance.

There are limitations of the current review, which include publication bias from selective inclusion of studies published in English and the lack of statistical pooling of the studies.

\section{Conclusions}

Overall, the present review has found that the effect of $\mathrm{Zn}$ supplementation on body composition may not be consistent. The review has suggested that $\mathrm{Zn}$ supplementation may have a beneficial effect on body composition, especially on FFM among children with pre-existing growth failure. However, variable findings resulting from technical difficulties in measuring body composition in community settings still need to be addressed. A majority of the studies could not accurately address whether alterations in the FM and/or FFM components of the body were responsible for the observed weight or body composition changes due to the use of anthropometry when determining body composition.

Further well-designed studies which measure body composition directly and address the limitations from previous studies are required. The determination of how adiposity-related hormone concentrations relate to body composition among supplemented children that differ in nutritional status may further clarify these relationships. Confirmation that $\mathrm{Zn}$ has an effect on body composition would allow the development of new public health interventions that may contribute to efforts to reduce the longterm risk of stunting, obesity and related diseases in the context of the global obesity pandemic.

\section{Acknowledgements}

Acknowledgements: The authors acknowledge the assistance of Assistant Professor Geoff C. Marks for his input on the research method. Financial support: This research received no specific grant from any funding agency in the public, commercial or not-for-profit sectors. Conflict of interest: None. Authorship: I.R.G. conceived the study and developed the overall research plan under supervision of K.Z.L. and A.A.-M. at all stages of its implementation. I.R.G. and K.Z.L. wrote the manuscript and have primary responsibility for final content. L.S. and A.A.-M. contributed in the final content. All authors read and approved the final manuscript. Ethics of human subject participation: Not applicable.

\section{References}

1. Kelly T, Yang W, Chen CS et al. (2008) Global burden of obesity in 2005 and projections to 2030. Int J Obes (Lond) 32, 1431-1437.

2. Finucane MM, Stevens GA, Cowan MJ et al. (2011) National, regional, and global trends in body-mass index since 1980: systematic analysis of health examination surveys and epidemiological studies with 960 country-years and $9 \cdot 1$ million participants. Lancet 377, 557-567.

3. Jeyakumar SM, Vajreswari A \& Giridharan NV (2008) Vitamin A regulates obesity in WNIN/Ob obese rat; independent of stearoyl-CoA desaturase-1. Biochem Biophys Res Commun 370, 243-247.

4. Foss YJ (2009) Vitamin D deficiency is the cause of common obesity. Med Hypotheses 72, 314-321.

5. Gunanti IR, Marks GC, Al-Mamun A et al. (2014) Low serum vitamin B-12 and folate concentrations and low thiamin and riboflavin intakes are inversely associated with greater adiposity in Mexican American children. J Nutr 144, 2027-2033.

6. Marreiro DN, Fisberg M \& Cozzolino SM (2002) Zinc nutritional status in obese children and adolescents. Biol Trace Elem Res 86, 107-122.

7. Garcia OP, Long KZ \& Rosado JL (2009) Impact of micronutrient deficiencies on obesity. Nutr Rev 67, 559-572.

8. Li Y, Wang C, Zhu K et al. (2010) Effects of multivitamin and mineral supplementation on adiposity, energy expenditure and lipid profiles in obese Chinese women. Int $J$ Obes (Lond) 34, 1070-1077.

9. Ghayour-Mobarhan M, Taylor A, New SA et al. (2005) Determinants of serum copper, zinc and selenium in healthy subjects. Ann Clin Biochem 42, 364-375.

10. Singh RB, Beegom R, Rastogi SS et al. (1998) Association of low plasma concentrations of antioxidant vitamins, magnesium and zinc with high body fat per cent measured by bioelectrical impedance analysis in Indian men. Magnes Res 11, 3-10.

11. Cavan KR, Gibson RS, Grazioso CF et al. (1993) Growth and body composition of periurban Guatemalan children in relation to zinc status: a cross-sectional study. Am J Clin Nutr 57, 334-343.

12. Gibson RS, Skeaff M \& Williams S (2000) Interrelationship of indices of body composition and zinc status in 11-yr-old New Zealand children. Biol Trace Elem Res 75, 65-77.

13. Ferguson EL, Gibson RS, Opare-Obisaw C et al. (1993) The zinc nutriture of preschool children living in two African countries. J Nutr 123, 1487-1496.

14. Galan P, Viteri FE, Bertrais S et al. (2005) Serum concentrations of $\beta$-carotene, vitamins $\mathrm{C}$ and $\mathrm{E}$, zinc and selenium are influenced by sex, age, diet, smoking status, alcohol consumption and corpulence in a general French adult population. Eur J Cin Nutr 59, 1181-1190. 
15. Weisstaub G, Hertrampf E, Lopez de Romana D et al. (2007) Plasma zinc concentration, body composition and physical activity in obese preschool children. Biol Trace Elem Res 118, $167-174$.

16. Ninh NX, Thissen JP, Collette L et al. (1996) Zinc supplementation increases growth and circulating insulin-like growth factor I (IGF-I) in growth-retarded Vietnamese children. Am J Clin Nutr 63, 514-519.

17. Castillo-Duran C, Garcia H, Venegas P et al. (1994) Zinc supplementation increases growth velocity of male children and adolescents with short stature. Acta Paediatr 83, 833-837.

18. Golden MH \& Golden BE (1981) Effect of zinc supplementation on the dietary intake, rate of weight gain, and energy cost of tissue deposition in children recovering from severe malnutrition. Am J Clin Nutr 34, 900-908.

19. McClain C, Stuart M, Kasarskis E et al. (1993) Zinc, appetite regulation and eating disorders. Prog Clin Biol Res 380, 47-64.

20. Golden BE \& Golden MH (1981) Plasma zinc, rate of weight gain, and the energy cost of tissue deposition in children recovering from severe malnutrition on a cow's milk or soya protein based diet. Am J Clin Nutr 34, 892-899.

21. Institute of Medicine (editor) (2001) Vitamin A. In Dietary Reference Intakes for Vitamin A, Vitamin K, Arsenic, Boron, Chromium, Copper, Iodine, Iron, Manganese, Molybdenum, Nickel, Silicon, Vanadium, and Zinc, pp. 82-161. Washington, DC: The National Academy Press.

22. Marreiro DN, Geloneze B, Tambascia MA et al. (2006) Effect of zinc supplementation on serum leptin levels and insulin resistance of obese women. Biol Trace Elem Res 112, 109-118.

23. Chen MD, Song YM \& Lin PY (2000) Zinc may be a mediator of leptin production in humans. Life Sci 66, 2143-2149.

24. Hashemipour M, Kelishadi R, Shapouri J et al. (2009) Effect of zinc supplementation on insulin resistance and components of the metabolic syndrome in prepubertal obese children. Hormones (Athens) 8, 279-285.

25. Brown KH, Peerson JM \& Allen LH (1998) Effect of zinc supplementation on children's growth: a meta-analysis of intervention trials. Bibl Nutr Dieta issue 54, 76-83.

26. Park JH, Grandjean CJ, Antonson DL et al. (1986) Effects of isolated zinc deficiency on the composition of skeletal muscle, liver and bone during growth in rats. J Nutr $\mathbf{1 1 6}$, 610-617.

27. Gluckman PD \& Hanson MA (2004) Living with the past: evolution, development, and patterns of disease. Science 305, 1733-1736.

28. Barker DJ (1990) The fetal and infant origins of adult disease. BMJ 301, 1111.

29. Hoffman DJ, Sawaya AL, Verreschi I et al. (2000) Why are nutritionally stunted children at increased risk of obesity? Studies of metabolic rate and fat oxidation in shantytown children from Sao Paulo, Brazil. Am J Clin Nutr 72, 702-707.

30. Sawaya AL, Grillo LP, Verreschi I et al. (1998) Mild stunting is associated with higher susceptibility to the effects of high fat diets: studies in a shantytown population in SaO Paulo, Brazil. J Nutr 128, 2 Suppl., 415S-420S.

31. Schardt C, Adams MB, Owens T et al. (2007) Utilization of the PICO framework to improve searching PubMed for clinical questions. BMC Med Inform Decis Mak 7, 16.

32. Liberati A, Altman DG, Tetzlaff J et al. (2009) The PRISMA statement for reporting systematic reviews and metaanalyses of studies that evaluate healthcare interventions: explanation and elaboration. BMJ 339, b2700.

33. Altman D, Schulz K, Moher D et al. (2001) The revised CONSORT statement for reporting randomized trials: explanation and elaboration. Ann Intern Med 134, 663-694.
34. Hills AP, Lyell L \& Byrne NM (2001) An evaluation of the methodology for the assessment of body composition in children and adolescents. In Medicine and Sport Science. vol. 44: Body Composition Assessment in Children and Adolescents, pp. 1-3 [T Jurimae and AP Hills, editors]. Basel: Karger.

35. Gibson R (2005) Principles of Nutritional Assessment, 2nd ed. Oxford: Oxford University Press.

36. Wells JC \& Fewtrell MS (2006) Measuring body composition. Arch Dis Child 91, 612-617.

37. Arsenault JE, Lopez de Romana D, Penny ME et al. (2008) Additional zinc delivered in a liquid supplement, but not in a fortified porridge, increased fat-free mass accrual among young Peruvian children with mild-to-moderate stunting. J Nutr 138, 108-114.

38. Diaz-Gomez NM, Domenech E, Barroso F et al. (2003) The effect of zinc supplementation on linear growth, body composition, and growth factors in preterm infants. Pediatrics 111, 1002-1009.

39. Walravens PA, Hambidge KM \& Koepfer DM (1989) Zinc supplementation in infants with a nutritional pattern of failure to thrive: a double-blind, controlled study. Pediatrics 83, 532-538.

40. Arsenault JE, Havel PJ, Lopez de Romana D et al. (2007) Longitudinal measures of circulating leptin and ghrelin concentrations are associated with the growth of young Peruvian children but are not affected by zinc supplementation. Am J Clin Nutr 86, 1111-1119.

41. Bueno O, Bueno G, Moreno LA et al. (2008) Zinc supplementation in infants with asymmetric intra uterine growth retardation; effect on growth, nutritional status and leptin secretion. Nutr Hosp 23, 212-219.

42. Kelishadi R, Hashemipour M, Adeli K et al. (2010) Effect of zinc supplementation on markers of insulin resistance, oxidative stress, and inflammation among prepubescent children with metabolic syndrome. Metab Syndr Relat Disord 8, 505-510.

43. Cavan KR, Gibson RS, Grazioso CF et al. (1993) Growth and body composition of periurban Guatemalan children in relation to zinc status: a longitudinal zinc intervention trial. Am J Clin Nutr 57, 344-352.

44. Friis H, Ndhlovu P, Mduluza T et al. (1997) The impact of zinc supplementation on growth and body composition: a randomized, controlled trial among rural Zimbabwean schoolchildren. Eur J Clin Nutr 51, 38-45.

45. Kikafunda JK, Walker AF, Allan EF et al. (1998) Effect of zinc supplementation on growth and body composition of Ugandan preschool children: a randomized, controlled, intervention trial. Am J Clin Nutr 68, 1261-1266.

46. Zemel BS, Kawchak DA, Fung EB et al. (2002) Effect of zinc supplementation on growth and body composition in children with sickle cell disease. Am J Clin Nutr 75, 300-307.

47. Rivera JA, Ruel MT, Santizo MC et al. (1998) Zinc supplementation improves the growth of stunted rural Guatemalan infants. J Nutr 128, 556-562.

48. Bates CJ, Evans PH, Dardenne M et al. (1993) A trial of zinc supplementation in young rural Gambian children. BrJ Nutr 69, 243-255.

49. Radhakrishna KV, Hemalatha R, Geddam JJ et al. (2013) Effectiveness of zinc supplementation to full term normal infants: a community based double blind, randomized, controlled, clinical trial. PLoS One 8, e61486.

50. Rosado JL, Lopez P, Munoz E et al. (1997) Zinc supplementation reduced morbidity, but neither zinc nor iron supplementation affected growth or body composition of Mexican preschoolers. Am J Clin Nutr 65, 13-19.

51. Umeta M, West CE, Haidar J et al. (2000) Zinc supplementation and stunted infants in Ethiopia: a randomised controlled trial. Lancet 355, 2021-2026. 
52. Heinig MJ, Brown KH, Lonnerdal B et al. (2006) Zinc supplementation does not affect growth, morbidity, or motor development of US term breastfed infants at 4-10 mo of age. Am J Clin Nutr 84, 594-601.

53. Ruz M, Castillo-Duran C, Lara X et al. (1997) A 14-mo zinc-supplementation trial in apparently healthy Chilean preschool children. Am J Clin Nutr 66, 1406-1413.

54. Brown KH, Peerson JM, Rivera J et al. (2002) Effect of supplemental zinc on the growth and serum zinc concentrations of prepubertal children: a meta-analysis of randomized controlled trials. Am J Clin Nutr $\mathbf{7 5}$, 1062-1071.

55. Stammers AL, Lowe NM, Medina MW et al. (2015) The relationship between zinc intake and growth in children aged 1-8 years: a systematic review and meta-analysis. Eur J Clin Nutr 69, 147-153.

56. Dorup I \& Clausen T (1991) Effects of magnesium and zinc deficiencies on growth and protein synthesis in skeletal muscle and the heart. Br J Nutr 66, 493-504.

57. Nishi Y (1996) Zinc and growth. J Am Coll Nutr 15, 340-344.

58. Bunce GE (1994) Interactions between zinc, vitamins A and $\mathrm{D}$, and hormones in the regulation of growth. Adv Exp Med Biol 352, 257-264.

59. Lonnerdal B (2000) Dietary factors influencing zinc absorption. J Nutr 130, 5S Suppl., 1378S-1383S.

60. Sandstrom B, Davidsson L, Cederblad A et al. (1985) Oral iron, dietary ligands and zinc absorption. J Nutr 115, 411-414.

61. Fleet JC (2000) Zinc, copper, and manganese. In Biochemical and Physiological Aspects of Human Nutrition, pp. 741-760 [MH Stipanuk, editor]. Philadelpia, PA: W.B. Saunders Company.

62. Brown KH, Rivera JA, Bhutta $\mathrm{Z}$ et al. (2004) International Zinc Nutrition Consultative Group (IZiNCG) technical document \#1. Assessment of the risk of zinc deficiency in populations and options for its control. Food Nutr Bull 25, 1 Suppl. 2, S99-S203.

63. Lopez de Romana D, Salazar M, Hambidge KM et al. (2005) Longitudinal measurements of zinc absorption in Peruvian children consuming wheat products fortified with iron only or iron and 1 of 2 amounts of zinc. Am J Clin Nutr $\mathbf{8 1}$, 637-647.

64. Rohner-Jeanrenaud F \& Jeanrenaud B (1996) Obesity, leptin, and the brain. N Engl J Med 334, 324-325.
65. Klok MD, Jakobsdottir S \& Drent ML (2007) The role of leptin and ghrelin in the regulation of food intake and body weight in humans: a review. Obes Rev 8, 21-34.

66. Ellis KJ \& Nicolson M (1997) Leptin levels and body fatness in children: effects of gender, ethnicity, and sexual development. Pediatr Res 42, 484-488.

67. Dencker M, Thorsson O, Karlsson MK et al. (2006) Leptin is closely related to body fat in prepubertal children aged 8-11 years. Acta Paediatr 95, 975-979.

68. Baltaci AK, Mogulkoc R \& Halifeoglu I (2005) Effects of zinc deficiency and supplementation on plasma leptin levels in rats. Biol Trace Elem Res 104, 41-46.

69. Mantzoros CS, Prasad AS, Beck FW et al. (1998) Zinc may regulate serum leptin concentrations in humans. J Am Coll Nutr 17, 270-275.

70. Chen MD, Song YM \& Lin PY (2000) Zinc effects on hyperglycemia and hypoleptinemia in streptozotocininduced diabetic mice. Horm Metab Res 32, 107-109.

71. Mantzoros CS (1999) The role of leptin in human obesity and disease: a review of current evidence. Ann Intern Med 130, 671-680.

72. Friedman JM \& Halaas J (1998) Leptin and the regulation of body weight in mammals. Nature 395, 763-770.

73. Moore SE, Falorni A, Bini V et al. (2004) Ethnic differences in the relationship between fasting leptin and BMI in children. Int J Obes Relat Metab Disord 28, 17-21.

74. Considine RV, Sinha MK, Heiman ML et al. (1996) Serum immunoreactive-leptin concentrations in normal-weight and obese humans. $N$ Engl J Med 334, 292-295.

75. Jequier E (2002) Leptin signal, adiposity, and energy balance. Ann N Y Acad Sci 967, 379-388.

76. Jaquet D, Leger J, Levy-Marchal C et al. (1998) Ontogeny of leptin in human fetuses and newborns: effect of intrauterine growth retardation on serum leptin concentrations. J Clin Endocrinol Metab 83, 1243-1246.

77. Sarraf P, Frederich RC, Turner EM et al. (1997) Multiple cytokines and acute inflammation raise mouse leptin levels: potential role in inflammatory anorexia. J Exp Med 185, 171-175.

78. Mast M, Kortzinger I, Konig E et al. (1998) Gender differences in fat mass of 5-7-year old children. Int J Obes Relat Metab Disord 22, 878-884.

79. Arfai K, Pitukcheewanont PD, Goran MI et al. (2002) Bone, muscle, and fat: sex-related differences in prepubertal children. Radiology 224, 338-344. 